\title{
Comments on "Deccan flood basalts at the Cretaceous/Tertiary boundary?" by V. Courtillot, J. Besse, D. Vandamme, R. Montigny, J.-J. Jaeger and H. Cappetta
}

\author{
Hans Wensink \\ Institute of Earth Sciences, Lirech (The Netherlands) \\ Received May 5. 1987: accepted June 21. 1987
}

The age of the flood basalts of the Deccan area and the length of the interval during which the outpourings took place are not known precisely. The authors [1] have tried to date those basalts and estimate how long the volcanic activity lasted: on the basis of new paleomagnetic, paleontological and geochronological data of the Deccan effusives they came to the preliminary conclusion that the volcanic activity may have lasted less than 1 $\mathrm{Ma}$ and that the majority of the lavas poured out during chron $29 \mathrm{R}$.

Unfortunately, the authors were not familiar with our paper on paleomagnetism and radiometric age determinations of Deccan Trap lavas [2]. In our paper we presented the paleomagnetic data derived from 223 individual lava flows from 16 sections all over the Deccan area and gave the $\mathrm{K}$-Ar age determinations for 13 selected, unaltered lava flows. We agree that the enormous volume of Deccan extrusives poured out in a relatively short interval and that the volcanic activity was probably concerned with the spreading in the central Indian Ocean in Late Cretaceous and Early Tertiary time.

Our paleomagnetic analysis showed that the majority of the lavas have a reversed magnetic polarity. So it is possible that these lavas flowed out during one particular reversed chron, because in several very long sections made up of reversed flows we did not come across any intercalated flows with a normal magnetic polarity.

The question that now arises is: during which chron did these flows pour out? Courtillot et al. [1] put forward arguments in favour of chron 29R; the transition from Cretaceous to Tertiary occurs during this chron. The chrons 30R, 29R, 28R, and $27 R$ cover fairly short intervals of time. The chrons $31 \mathrm{R}$ and $26 \mathrm{R}$, however, take up periods of time of about $2 \mathrm{Ma}$ each. There are several publications about radiometric age determinations of Deccan lavas. Although the accuracy of the analytical ages is good, the results do not tell us precisely when the Deccan outpourings occurred. Our results are also inconsistent with the stratigraphy of the lavas (see Fig. 1). Several K-Ar ages are lower than expected; the conventional explanation for this is that the rocks had lost varying proportions of the radiogenic argon that had been generated within the rocks since they had been formed. One of us (E.H.H.) came to the conclusion that through geological time in addition to a loss of radiogenic argon potassium may have been introduced into the rock systems. This conclusion was based on the fact that there is a rough correlation between the amount of the potassium present and the age determined. See also the recent paper by Baksi [3].

Fig. 1 shows that the youngest lavas generally have the greatest ages. Lavas from the upper part of the main reversed-Deccan-sequence give us mean ages of $64.2 \pm 3.6 \mathrm{Ma}$ ( 3 datings), and lavas from the overlying normal--Nipani-sequence yield ages of $60.5 \pm 2.8 \mathrm{Ma}$ (4 datings).

From our combined paleomagnetic study we concluded that the Deccan lavas may have poured out during four successive polarity chrons: two normal and two reversed chrons. In our opinion. the extrusions did not follow each other in rapid succession, because in most sections between 


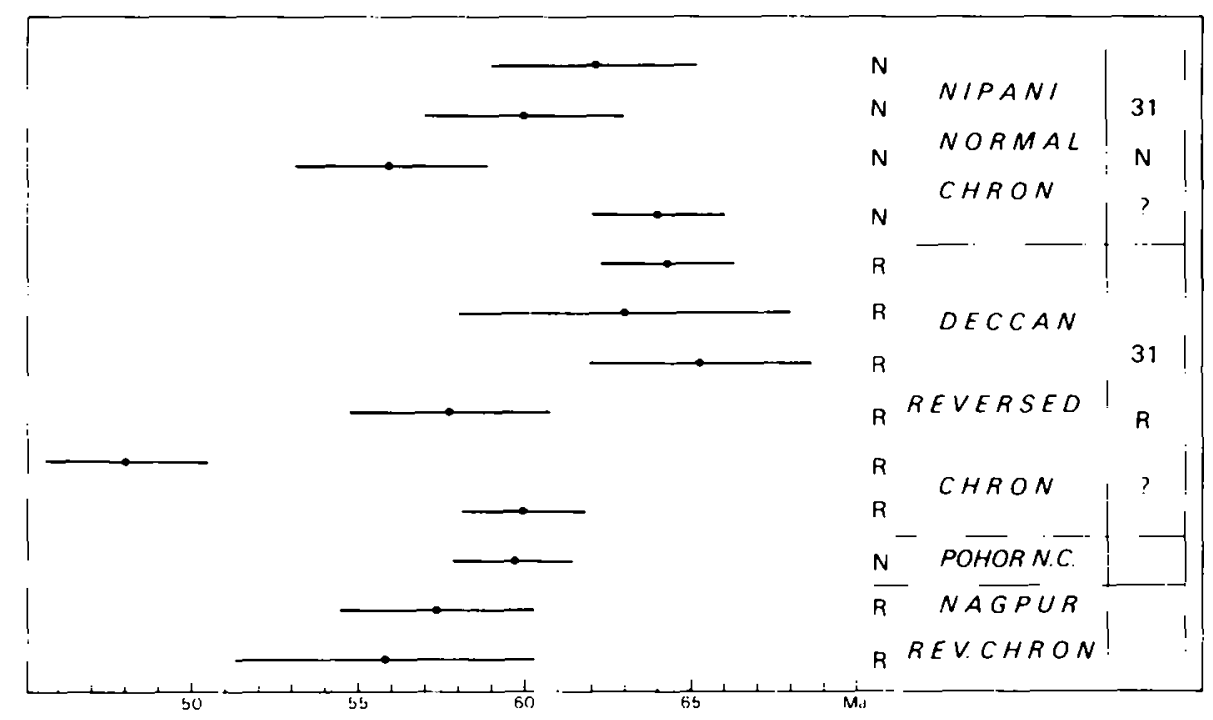

Fig. 1. Radiometric ages and error bars of Deccan lava flows in their stratigraphical order, and the determined paleomagnetic polarity stratigraphy with a possible correlation with the geomagnetic time scale.

successive lava flows red partings are intercalated; red partings are usually explained in terms of (heated) soils. In the Deccan area the lava sequence near Ellora, northwest of Aurangabad, is an exception because in that sequence there are no red partings between the consecutive fairly thin lava flows; this points to a rather rapid succession of outpourings.

In order to investigate whether or not the Indian subcontinent drifted northwards during the interval of Deccan volcanic activity, we compared. in a number of sections built up from many lava flows, the mean characteristic direction of magnetization of the combined lower flows with that of the combined upper flows. The derived positions of the virtual magnetic poles confirm that such a movement did occur. The same analysis performed on the possibly oldest Deccan flows near Nagpur and the youngest flows in the Western Ghats gave a polar distance of about $14^{\circ}$ for the derived virtual magnetic pole positions. If one assumes that these lava series differ in age by 5 Ma one can deduce a velocity of about $30 \mathrm{~cm} /$ year for the drift of India. Such a rate is not in conflict with the data of the rate of spreading in the Indian Ocean at that time. In the Indian Ocean, south of Sri Lanka, the magnetic anomalies 33-23 have been identified [4]. The interpretation of the anomalies 30 to 26 points to a rapid spreading of a half rate of about $12 \mathrm{~cm} /$ year, and thus to a 24 $\mathrm{cm} /$ year drift of the oceanic crust lying north of the ancient spreading centre if Antarctica remained in situ.

If one accepts that the majority of the Deccan lavas poured during one single reversed magnetic polarity chron only and that the identification of the marine magnetic anomalies in the Indian Ocean, south of Sri Lanka, is correct, then chron $31 \mathrm{R}$ must be considered as the main period of volcanic activity. This chron is underlain by a normal and a reversed chron which both are short lasting and which are possibly represented by the lava sequences near Nagpur. The age of chron $31 \mathrm{R}$ is not incompatible with the data for the radiometric age dates on Deccan lavas. Moreover, chron $31 \mathrm{R}$ covers a greater interval of time than chron $29 \mathrm{R}$. The purpose of this comment is not to give a definite answer to the Deccan age problem, but is simply to stress that in attempting to date a sequence one must take all available paleomagnetic, radiometric, paleontological and marine data in consideration.

\section{References}

1 V. Courtillot, J. Besse, D. Vandamme, R. Montigny, J.-J. Jaeger and $H$. Cappetta. Deccan flood basalts at the Creta- 
ceous/Tertiary boundary?, Earth Planet. Sci. Lett. 80. 361374.1986.

2 H. Wensink, N.I.A.M. Boelrijk, E.H. Hebeda, H.N.A. Priem, E.A.T. Verdurmen and R.H. Verschure, Paleomagnetism and radiometric age determinations of the Deccan Traps, India, in: Proc. IV Int. Gondwana Symp., (alcutta, India. pp. 832-849, Hindustan Publ. Corp.. Delhi. 1977.
3 A.K. Baksi, Critical evaluation of the age of the Deccan Traps, India: implications for flood-basalt volcanism and faunal extinctions, Geology 15, 147-150, 1987.

4 J.C. Sclater and R.L. Fisher, Evolution of the east central Indian Ocean with emphasis on the setting of the Ninety-east ridge, Geol. Soc. Am. Bull. 85, 683- 702, 1974. 